\title{
PARKINSONO LIGOS EPIDEMIOLOGIJA IR RIZIKOS VEIKSNIAI
}

\author{
Agnẻ Pacevičiūtė', Ramutė Šimkoniene் $\dot{e}^{2}$ \\ ${ }^{1}$ Lietuvos sveikatos mokslu universitetas, Medicinos akademija, Medicinos fakultetas, \\ ${ }^{2}$ Druskininku miesto ligonine, Neurologijos skyrius
}

Raktažodžiai: Parkinsono liga, rizikos veiksniai, epidemiologija.

\section{Santrauka}

Parkinsono liga (PL) yra kompleksinis neuropsichiatrinis sutrikimas, pasireiškiantis motoriniais ir nemotoriniais simptomais. Ši liga yra vienas dažniausių neurodegeneracinių sutrikimų - antra po Alzheimerio ligos, o jos paplitimas didèja su amžiumi. Liga dažnesnè vyrams, baltaodžių populiacijoje ir kaimo gyventojams.

PL priežastys nèra tiksliai nustatytos, tačiau manoma, kad ją lemia modifikuojamų ir nemodifikuojamų rizikos veiksnių derinys. Yra duomenų, jog kofeino, tabako vartojimas bei fizinis aktyvumas mažina ligos atsiradimo riziką, o pesticidai, pieno produktai, patiriamas stresas ir genetiniai veiksniai - didina.

\section{İvadas}

Parkinsono liga (PL) yra kompleksinis neuropsichiatrinis sutrikimas, pasireiškiantis įvairiais motoriniais ir nemotoriniais simptomais [1]. Klasikiniai motoriniai simptomai yra drebulys ramybès būsenoje, bradikinezija, rigidiškumas ir nestabili laikysena [2], kuriuos sukelia dopaminerginės nigrostriatinès sistemos pažeidimas [3], o nemotoriniai simptomai yra nuotaikos, pažinimo, miego ir autonominès funkcijos sutrikimai [4], kuriuos lemia tolimesnis PL progresavimas [3]. Pati PL nesukelia mirties, tačiau susijusi su padidèjusiu sergamumu ir mirtingumu [5]. Po maždaug 17 metų 80 proc. pacientų, sergančių PL, skundžiasi sustingusia eisena, kuri didina griuvimo riziką, o iki 50 proc. pacientų praneša, kad pradeda springti. Demencija yra vèlyvas PL požymis, pasireiškiantis 60 proc. pacientų, 10 metų sergančių šia liga ir 83 proc. pacientų, kurių ligos istorijai 20 metų.Vèlyvosios stadijos simptomai, tokie kaip demencija ir kritimas, yra dažniausios ilgalaikès priežiūros ir didelio mirtingumo priežastys [6].

PL etiopatogenezė vis dar neaiški, tačiau šiuo metu yra žinoma, jog ji susijusi su aplinkos, genetiniais ir imunologiais veiksniais [7].
Tyrimo tikslas - išsiaiškinti Parkinsono ligos paplitimą, rizikos veiksnius ir ligos atsiradimo riziką mažinančius veiksnius.

\section{Tyrimo objektas ir metodai}

$2021 \mathrm{~m}$. birželio mėnesị buvo atlikta sisteminè mokslinių straipsnių apžvalga. Mokslinès literatūros šaltinių paieškai pasirinkta publikacijų duomenų bazè PubMed ir raktažodžiai bei jų deriniai: Parkinson's disease AND risk factors AND epidemiology. Straipsnių atrankos kriterijai: publikacijos anglų kalba, atitinkančios tyrimo temą, paskelbtos nuo 2014 iki 2021 metų.

\section{Rezultatai ir jų aptarimas}

Epidemiologija. Didžiają istorijos dalị Parkinsono liga buvo retas sutrikimas. 1855 metais, praejjus keturiasdešimčiai metų po to, kai daktaras James Parkinson pirmą kartą apraše šią būklę, iš 15 milijonų žmonių Anglijoje ir Velse maždaug 15 sirgo šia liga. 2014 metais tą patị likimą patyrè apie 5-10 tūkst. asmenų iš 65 milijonų Jungtinèje Karalystejje. Nepraejus nè dvidešimtmečiui, šis retas sutrikimas tapo iprastiniu [8].

Šiuo metu PL yra vienas dažniausių neurodegeneracinių sutrikimų - antras po Alzheimerio ligos [1]. PL serga maždaug 0,3 proc. visų gyventojų ir manoma, jog sergamumas 2030 metais išaugs nuo 8,7 iki $9,3 \mathrm{mln}$. [2]. PL dažniausiai paveikia 60 metų žmones ir vyresnius, šiek tiek dažniau pasitaiko vyrams, nei moterims, santykis 1,5:1. Nors PL gali pasireikšti jau paauglystèje, dažnis didèja su amžiumi. Pranešama, kad PL paplitimas 85-89 metų amžiaus grupejje yra 2,6 proc., o 65-69 metu grupejje 0,6 procento. Nors ligai būdingas lètas progresavimas ir dauguma sergančiųjų išgyvena ilgiau nei dešimtmetį, daugeliui pasireiškia reikšminga fizinè ir kognityvinè negalia [1]. Daugelyje tyrimų buvo nustatyta, jog didžiausias PL paplitimas yra baltaodžiu populiacijoje. Geografinè padètis labiau lemia PL išsivystymą, nei etninè kilmé. Vienas iš pavyzdžių galètų būti tai, jog î pietus nuo Sacharos juodaodžių afrikiečių PL paplitimas yra mažesnis, nei afrikietiškos kilmės žmonių, gyvenančių JAV [9]. Dauguma tyrimų 
nurodè, kad PL dažniau pasitaiko kaimo gyventojams [10].

Rizikos veiksniai. PL priežastys nèra tiksliai nustatytos, tačiau, kaip ir sergant kitomis lètinėmis ligomis, manoma, kad PL lemia modifikuojamų (pvz., aplinkos poveikis, kuris didina ar mažina riziką) ir nemodifikuojamų veiksnių (pvz., genetinių) derinys. Modifikuojamų priežasčių suvokimas yra gyvybiškai svarbus PL valdymo visuomenès sveikatos politikai [4].

Modifikuojami veiksniai. Pesticidai. Epidemiologiniu tyrimų metu buvo nustatyta, kad PL yra susijusi su ūkininkavimu, gyvenimu kaime ir šulinio vandens vartojimu. Vèlesni tyrimai parodè, kad pesticidai iš tikrujų gali sukelti PL tiek gyvūnams, tiek žmonèms [11].

Rotenonas ir parakvatas yra du pesticidai, kurie sutrikdo kvėpavimo grandinę mitochondrijose ir sukelia oksidacini stresą. Šis ryšys sustiprejo, kai 1983 m. metil-fenil-tetrahidro-piridinu (MPTP) užteršto heroino vartojimas paskatino jaunų suaugusiųų parkinsonizmą. MPTP metabolizuojamas ị 1-metil-4-fenilpiridiniumą (MPP +), kuris sukelia panašų toksiškumą mitochondrijoms kaip rotenonas ir parakvatas [12].

Pienas ir pieno produktai. Keletas tyrimų parodè pieno ir jo produktų neurotoksinị poveikị, kuris yra grindžiamas tuo, jog pieno ir jo produktų vartojimas padidina oksidacini stresą per tarpląstelinị kalcio poveiki, arba per teršalus, tokius kaip rotenonas ir parakvatas, kurie veikia kaip toksinè medžiaga nigrostriatiniuose neuronuose [13]. Irodymų, kad pienas yra PL rizikos veiksnys, trūksta, todèl negalima rekomenduoti riboti pieno vartojimo, norint išvengti PL. Maisto produktai, turintys daug kalcio ir aukštos kokybès baltymų, neturètų būti ribojami, atsižvelgiant ị didelị osteoporozès ir klubo lūžių paplitimą sergant PL [14].

Stresas. Stresas apibrèžiamas kaip staigus nenuoseklus fizinis, fiziologinis ir socialinis aplinkos pokytis, kuri patiria organizmas. Streso poveikis ankstyvame amžiuje gali tureti trumpalaikị ar ilgalaiki poveikị smegenų vystymuisi [15]. Manoma, jog šis modifikuojamasis veiksnys gali būti laikomas PL ir kitų neurodegeneracinių sutrikimų rizikos veiksnys dèl tiesioginio neurotoksinio poveikio [16].

Nemodifikuojami veiksniai. Genetiniai veiksniai. Genetikos indèli i i PL rodo padidejjusi ligų, susijusių su šeimine PL istorija, rizika. Itikinamiausi įrodymai buvo atrasti monogeninès PL formos. SNCA, kuris koduoja baltymą $\alpha$-sinukleiną, buvo pirmasis genas, susijęs su paveldima PL. LRRK2 ir parkino genų mutacijos yra dažniausios dominuojančiu ir recesyviniu būdu paveldimos PL priežastys. Didžiausias genetinis PL išsivystymo rizikos veiksnys yra GBA mutacija, koduojanti $\beta$-gliukocerebrozidazę, lizosominị fermentą [17]. GBA mutacijos turi ryší su Gošè ligos rizika, kuri yra paveldima autosominiu recesyviniu būdu. Daugybė tyrimų pranešé apie GBA mutacijų ir PL ryšį. Pacientams, turintiems PL ir GBA mutacijas, būdingas panašus ligos fenotipas kaip ir pacientams, sergantiems idiopatine PL be GBA mutacijų, nors ramybès drebulys ir rigidiškumas ramybejje yra rečiau pasi- taikantis simptomas šiems pacientams, tačiau jiems pasireiškia ryškesni kognityviniai sutrikimai. Heterozigotinių GBA mutacijos nešiotojų taip pat didesnè rizika susirgti PL [18].

Per pastarajị dešimtmetị beveik 900 genetinių tyrimų parodè dešimtis galimų PL genų lokusų. Visų esamų Europos PL duomenų genomo masto asociacijos tyrimų metaanalizès rezultatai parodè, kad 24 lokusai turi kliniškai reikšmingą ryšį su ligos rizika. Šie lokusai apima GBA ir genus, susijusius su monogeninès PL formomis (LRRK2 ir SNCA) [17]. Nors ir šie genai kelia nedidelę riziką susirgti PL, tačiau sąveikaudami su nepalankiais aplinkos veiksniais, jie gali sukelti PL [18].

Veiksniai, mažinantys Parkinsono ligos atsiradimą. Kofeinas. Tyrimai, kurių metu buvo ištirtas kofeino poveikis PL vystymuisi, parodè mažesnę PL išsivystymo riziką tarp kavos mėgėju. Kofeinas yra adenozino $\mathrm{A}_{2 \mathrm{~A}}$ receptorių antagonistas, kuris, kaip manoma, apsaugo nuo PL. Anksčiau buvo pranešta, kad kavos mėgejų rizika susirgti PL sumažeja 25 procentais. Du dideli perspektyviniai epidemiologiniai ir daugybė retrospektyvinių tyrimų taip pat parodė mažesnę riziką susirgti PL [19].

Tabakas. Idejja, kad tabako rūkymas gali sumažinti PL riziką buvo paskelbta prieš 60 metų. Nuo to laiko vis daugiau duomenų rodo, kad tabako rūkymas, kuris yra pagrindinè ankstyvos mirties priežastis ir kone visų kitų neužkrečiamuju ligų rizikos veiksnys, yra susijęs su sumažejusia PL rizika [20]. Gyventojų tyrimai parodè, kad rūkymas buvo susijęs su maždaug 40-50 proc. mažesne rizika susirgti PL. Atlikus epidemiologinius tyrimus buvo nustatyta, jog aplinkos tabako dūmų poveikis taip pat susijęs su žymiai mažesne PL rizika tarp niekada aktyviai nerūkiusių žmonių [21]. Manoma, kad teigiamą rūkymo poveikị lemia galimas gydomasis nikotino poveikis, kuris, kaip buvo ịrodyta tyrimuose su gyvūnais, yra neuroprotekcinis. Solanaceae šeimos augalai, kuriuose yra nikotino, įskaitant pipirus, pomidorus, bulves ir baklažanus buvo ištirti Vakarų Vašingtono valstijos tyrime. Nustatyta, kad rizika susirgti Parkinsono liga sumažèja vartojant Solanaceae šeimos daržoves, ypač tas, kuriose yra didesnè nikotino koncentracija [22].

Fizinis aktyvumas. Fizinis aktyvumas yra svarbus PL prevencijai ir gydymui. Apie fizinio aktyvumo ir PL rizikos ryši pirmiausia buvo pranešta Slaugytojų sveikatos tyrime, o vèliau ir kituose tyrimuose. Perspektyvinių epidemiologinių tyrimų rezultatai rodo, kad fizinis aktyvumas mažina vyrų PL riziką, tačiau mechanizmas nèra aiškus [23].

\section{Išvados}

1. Parkinsono liga yra antras pagal dažnumą neurodegeneracinis sutrikimas, labiausiai paplitęs tarp vyrų, baltaodžiu populiacijoje bei kaimo vietovèse.

2. Ligos tikslios priežastys nèra nustatytos, tačiau manoma, jog ją sukelia modifikuojamų ir nemodifikuojamų rizikos veiksnių derinys. 
3. Ligos atsiradimą didina pesticidų, pieno produktų vartojimas, stresas bei genetiniai veiksniai. Riziką mažina fizinis aktyvumas, kofeino bei tabako vartojimas.

\section{Literatūra}

1. Deeb W, Nozile-Firth K, Okun MS. Parkinson's disease: Diagnosis and appreciation of comorbidities. Handb Clin Neurol 2019; 167:257-77.

https://doi.org/10.1016/B978-0-12-804766-8.00014-5

2. Raza C, Anjum R, Shakeel NUA. Parkinson's disease: Mechanisms, translational models and management strategies. Life Sci 2019;226:77-90. https://doi.org/10.1016/j.lfs.2019.03.057

3. Pajares M, I Rojo A, Manda G, Boscá L, Cuadrado A. Inflammation in Parkinson's Disease: Mechanisms and Therapeutic Implications. Cells 2020;9(7):1687.

https://doi.org/10.3390/cells9071687

4. Lee A, Gilbert RM. Epidemiology of Parkinson Disease. Neurol Clin 2016;34(4):955-965. https://doi.org/10.1016/j.ncl.2016.06.012

5. Beitz JM. Parkinson's disease: A review. Front Biosci (Schol Ed) 2014;6:65-74.

https://doi.org/10.2741/S415

6. Capriotti T, Terzakis K. Parkinson Disease. Home Healthe Now 2016;34(6):300-7. https://doi.org/10.1097/NHH.0000000000000398

7. De Virgilio A, Greco A, Fabbrini G, Inghilleri M, Rizzo MI, Gallo A, et al. Parkinson's disease: Autoimmunity and neuroinflammation. Autoimmun Rev 2016;15(10):1005-11. https://doi.org/10.1016/j.autrev.2016.07.022

8. Dorsey ER, Sherer T, Okun MS, Bloemd BR. The emerging evidence of the Parkinson pandemic. J Parkinsons Dis 2018;8(s1):S3-S8.

https://doi.org/10.3233/JPD-181474

9. Ben-Joseph A, Marshall CR, Lees AJ, Noyce AJ. Ethnic Variation in the Manifestation of Parkinson's Disease: A Narrative Review. J Parkinsons Dis 2020;10(1):31-45.

https://doi.org/10.3233/JPD-191763

10. Jagadeesan AJ, Murugesan R, Vimala Devi S, Meera M, Madhumala G, Vishwanathan Padmaja M, et al. Current trends in etiology, prognosis and therapeutic aspects of Parkinson's. Acta Biomed 2017;88(3):249-262.

11. Nandipati S, Litvan I. Environmental exposures and Parkinson's disease. Int J Environ Res Public Health 2016;13(9):881. https://doi.org/10.3390/ijerph13090881

12. Zhang PL, Chen Y, Zhang CH, Wang YX, Fernandez-Funez P. Genetics of Parkinson's disease and related disorders. J Parkinsons Dis 2020;10(1):31-45

13. Boulos C, Yaghi N, El Hayeck R, Heraoui GN, FakhourySayegh N. Nutritional Risk Factors, Microbiota and Parkinson's Disease: What Is the Current Evidence? Nutrients 2019;11(8):1896.

https://doi.org/10.3390/nu11081896

14. Kistner A, Krack P. Parkinson's disease: No milk today? Front Neurol 2014; 5:172. https://doi.org/10.3389/fneur.2014.00172

15. Dallé E, Mabandla M V. Molecular Brain. Early Life Stress, Depression And Parkinson's Disease: A New Approach. Mol Brain 2018;11(1):18. https://doi.org/10.1186/s13041-018-0356-9

16. Marras C, Canning CG, Goldman SM. Environment, lifestyle, and Parkinson's disease: Implications for prevention in the next decade. Mov Disord 2019;34(6):801-811. https://doi.org/10.1002/mds.27720

17. Kalia L V., Lang AE. Parkinson's disease. Lancet 2015;386(9996):896-912. https://doi.org/10.1016/S0140-6736(14)61393-3

18. Delamarre A, Meissner WG. Épidémiologie, facteurs de risque environnementaux et génétiques de la maladie de Parkinson. Press Medicale 2017;46(2 Pt 1):175-181.

19. Kouli A, Torsney KM, Kuan W-L. Parkinson's Disease: Etiology, Neuropathology, and Pathogenesis. Codon Publications 2018; Chapter1:3-26.

https://doi.org/10.15586/codonpublications.parkinsonsdisease.2018.ch1

20. Cheng Y, Wang YJ. Tobacco smoking and the reduced risk of Parkinson disease: A puzzle of 60 years. Neurology 2020;94(20):860-861.

https://doi.org/10.1212/WNL.0000000000009431

21. Ma C, Liu Y, Neumann S, Gao X. Nicotine from cigarette smoking and diet and Parkinson disease: A review. Transl Neurodegener 2017;6:18.

https://doi.org/10.1186/s40035-017-0090-8

22. Abbas MM, Xu Z, Tan LCS. Epidemiology of Parkinson's Disease - East Versus West. Mov. Disord. Clin. Pract. 2017;5(1):14-28.

https://doi.org/10.1002/mdc3.12568

23. Fan B, Jabeen R, Bo B, Guo C, Han M, Zhang H, et al. What and How Can Physical Activity Prevention Function on Parkinson's Disease? Oxid Med Cell Longev 2020; 2020:4293071. https://doi.org/10.1155/2020/4293071

\section{EPIDEMIOLOGY AND RISK FACTORS OF PARKINSON'S DISEASE}

\section{A. Pacevičiūtè, R. Šimkonienė}

Keywords: Parkinson's disease, risk factors, epidemiology. Summary

Parkinson's disease (PL) is a complex neuropsychiatric disorder with motor and non-motor symptoms. The disease is one of the most common neurodegenerative disorders, second after Alzheimer's disease, and its prevalence increases with age. The disease is also more common in men, Caucasians and for the rural population. The causes of PL are not precisely identified, but are thought to be due to a combination of modified and unmodified risk factors. There is evidence that caffeine, tobacco use and physical activity reduce the risk of disease, while pesticides, dairy products, stress and genetic factors increase it.

Correspondence to: agnytepa@gmail.com

Gauta 2021-09-24 